Is the benefactor of mankind, Thus it is that the tangible utility of scientific results has convinced the State that laboratory work should be encouraged and sustained, because it is economically a benefit to all, and for the public health. Science carries still further its legitimate pretensions. It claims today at once the material direction, the intellectual direction, and the moral direction of human society. Under its impulse modern civilisation marches with a more and more rapid stride.

Since the first half of the century that has just gone by, not to go further back, the world has strangely changed its face. Men of my generation have beheld coming on the scene by the side of and above that nature which had been known since antiquity, if not an antiphysis, a counter nature, as is sometimes said, yet a superior and in a way transcendent nature where the power of the individual is multiplied a hundredfold by the transformation, hitherto unknown or not understood, borrowed from light, magnetism and electricity. Nor is this all. Let us rise to a loftier and more fruitful range of ideas. From the deeper knowledge of the universe and the physical and moral constitution of man there results a fresh conception of human destiny governed by the fundamental ideas of human solidarity between all classes and all nations. In proportion as the ties uniting the peoples are multiplied and made tighter by the progress of science and the unity of doctrines and precepts which science deduces from the facts which it notes and which it imposes without violence, yet relentlessly, upon all convictions, these ideas have assumed a growing and more and more irresistible importance. They are tending to become the purely human bases of moral life and of the politics of the future. Hence the rôle of savants as individuals and as a social class has constantly grown in modern States.

But our duties towards other men grow at the same time, let us never forget that. Let us proclaim it in this enclosure, in this palace of French science. It is for no selfish satisfaction of our private vanity that to-day the world does homage to the savants. No! It is because it is aware that a savant really worthy of the name devotes a disinterested life to the great work of our epoch, I mean to the amelioration, too slow, alas, to our mind, of the lot of all, from the rich and fortunate to the humble, the poor, the suffering. This was what nine years ago in this very hall the State and the authorities affirmed by honouring Pasteur. This is what my friend Chaplain has sought to express on this fine medal which the President of the Republic is to offer me. I know not if I have completely fulfilled the noble ideal traced by the artist, but I have striven, at all events, to make it the object and the end, the governing aim of my existence.

The medal (or rather plaque) with suitable inscription was then presented to M. Berthelot by M. Loubet, the President of the Republic, and, according to continental fashion, the ceremony was concluded with a fraternal embrace.

Such is a brief account of the proceedings at this very interesting ceremony; and one is led to seek for analogies in our own country. The Kelvin jubilee at Glasgow and the Stokes jubilee at Cambridge may be cited as events of a similar character ; but in France the ceremony appeared to be of greater national importance, owing to the presence of the Head of the State, the Ministers and the Ambassadors. In his reply M. Berthelot alluded humorously to the former position of science; it was regarded as a harmless pursuit, carried on by amateurs and men of leisure at the charge of the working classes, for the amusement and distraction of those favoured by fortune; it has now become one of the most potent influences for civilisation that the world has known, and will ever retain that position. Is it possible that in England the former view of science still retains some hold on the people, and that in France this aspect of science has long been outlived? Whether this be so or not it is certain that all Englishmen will join with the whole French nation in congratulating $M$. Berthelot on the completion of so many years of work and will wish him health and a long life during which he may enrich the world by further investigations into the wide domain of Nature.

NO. I674, VOL. 65$]$

\section{BERTHELOT, AND THE METALS OF ANTIQUITY.} $\mathrm{HE}$ metals of antiquity are among the many subjects
which, from time to time, have been studied by M. Berthelot. It is principally by two different methods that he has investigated the matter: (I) the writings of ancient alchymists, (2) the analysis of metallic objects sent him by modern explorers. In 1885 Berthelot pub. lished a handsome volume, "Les Origines de l'Alchimie," in which he described his researches among the Greek papyri, and the still older documents of the Egyptian, Chaldean, Jewish, Gnostic and Chinese philosophers. In succeeding years he brought out several volumes under the title of "Collection des Anciens Alchimistes Grecs," under the auspices of the Minister of Public Instruction.

By far the most important for the present purpose is the collection of papyritat Leyden. The Papyrus $\mathrm{X}$ is more especially chemical. It dates from the end of the third century, but contains the lore of earlier times. It is described in fairly full detail in the Annales de Chimie et de Physique, 1886, vol. ix. Berthelot shows that the earlier alchemy was not founded upon purely chimerical fancies, but rests upon positive experiment, by which the adepts made imitations of gold and silver and precious stones, or taught how to increase their weight. In interpreting these ancient writings we are met with a great difficulty in fixing the meaning of the terms used for the metals and gems and the preparations made from them, the vagueness of the language being augmented by the idea that these substances were susceptible of transmutation into one another, and also by the Platonic doctrine of a primary matter from which everything may be derived. In this particular papyrus there are no less than Ior receipts for making gold, asèm (electrum), silver, $\& c$, and the processes to be adopted. These are described by Berthelot as being genuine and definite, and not overlaid with fanciful notions ; but the later philosophers and commentators were strangers to practical work and governed by mystic ideas: thus there was supposed to be a connection between the seven known metals and the seven planets, seven colours and seven transmutations. The later alchymists threw their energies into the search after the philosopher's stone which was to transmute baser metals into gold.

More important, perhaps, than his studies of the ancient manuscripts has been the prominent part which Berthelot has taken in examining chemically the metallic objects which have been unearthed by the great explorers of the present day. These researches are being carried on over the greater part of the countries bordering the Mediterranean and extending to the Persian Gulf. It is hardly necessary to say that they are enabling us to picture to ourselves these great nationalities of old in a way that was never before possible. The part that Berthelot has taken is not that of an explorer, but that of a scientific analyst; and it has been mainly confined to the metals employed in these ancient civilisations. He commenced by examining different Assyrian objects from ancient Chaldæa, some from the palace of Sargon at Khorsabad, others from the mounds of Tello excavated by M. de Sarzec, now in the museum of the Louvre. M. Place had found in the palace of Sargon a stone coffer containing votive tablets, covered with cuneiform inscriptions giving the date of foundation of the palace as B.C. 706 . Of the four now in the museum of the Louvre, one is of gold, another of silver, a third of bronze and the fourth of the rare mineral crystallised carbonate of magnesia. Judging from the inscriptions two of the other tablets are believed to have been of lead and tin. The discoveries at Tello consisted of a vase of antimony, a metal which had subsequently been lost sight of for many centuries; a tablet of metallic copper, much corroded, but free from tin ; and a little figure of pure copper, bearing the name 
of King Gudea, which fixes its date somewhere about 4000 years before the Christian era. This led Berthelot to speculate why these specimens were made of copper instead of the harder bronze, which, so far as his experience had then gone, was used by all the ancients. He applied to Maspero for some specimens of the oldest copper of which the date could be identified. Maspero recommended to him the so-called sceptre of Pepi I., an Egyptian king of the sixth dynasty, 3500-4000 B.C. This was in the British Museum, but, through the good offices of M. Waddington, it was placed in the hands of $M$. Berthelot with permission to analyse a small portion from the interior. It proved to be of pure copper. It was a natural supposition that tin was unknown in that remote age ; and this was confirmed by the discovery in Chaldæa of some little figures serving to support votive tablets, associated with bricks that bore the name of King Ourmina, who is supposed to have reigned 4000 years B.C. They were also of copper, without either tin or zinc.

In the meantime Prof. Flinders Petrie had been carrying on his excavations in Egypt and had asked me to analyse some copper tools and utensils from early tombs and other ruins. They proved to contain little or no tin, though many of them contained arsenic. Evidence of the gradual transition from the use of pure copper to that of copper alloyed with tin was accumulating from various quarters, but the most striking, perhaps, was that furnished by Tell el Hesy, the Lachish of scripture. It was explored by Mr. F. J. Bliss, and is described in his book entitled "A Mound of Many Cities." The lower portion of this mound represents the Amorite city, dating about I 700 B.C. ; it contained large weapons of war made of copper without admixture of tin. Above this are the remains of the Israelitish city, where the copper is replaced by bronze, till in the upper layers of the mound the bronze is gradually replaced by iron. Greece has also furnished its contributions. The analyses of Roberts-Austen, Damour and others had shown that the implements first used at Tyryns, Mikenai and other towns were of copper with little, if any, admixtere of tin; and similar evidence is coming forward from Cyprus, Crete and other quarters. At Hissarlik, the reputed Troy, the analysis of the objects found in the first and second cities showed that they were made of copper with mere traces of tin, while in the third and more recent cities the copper was mixed with varying amounts of tin, from 4 to 8 per cent. or thereabouts.

These researches were followed by an important paper in the Annales of 1895, in which Berthelot discussed the nature and origin of the metals employed by the ancient Egyptians of various epochs, especially copper, tin, gold and silver. The general result was that up to the sixth dynasty the copper used was practically what they obtained from the ores; after this the copper was mixed with small quantities of tin, rarely exceeding 6 per cent. At about the twelfth dynasty Io per cent. became the usual proportion, forming a very serviceable bronze, but occasionally as inuch as 16 per cent. was used.

In the same paper he investigates the cause of the "sickness" of copper objects in our museums. They often fall to pieces through the formation of atacamite, a cupric oxychloride. This is started by the presence of chloride of sodium in the soil and the carbonic acid and oxygen of the air, and is a curious and complicated case of continuous chemical action.

It became a matter of interest to explore the ancient workings for copper, turquoise and hæmatite in Wady Maghara in the Sinaitic peninsula, which is known to have been a source of supply in the time of the third Egyptian dynasty. M. de Morgan made a careful search, at $\mathrm{M}$. Berthelot's instigation, and found not only specimens of the ores, but also remains of the tools that had been used. The mines are believed to have been abandoned about the time of the eighteenth dynasty, in NO. I 674 , VOL. 65$]$ consequence of the poverty of the ores. The tools were of copper, hardened sometimes by a little tin and at other times by arsenic.

More recently Berthelot has examined some copper objects found at Tello, believed to be of very high antiquity. One was a huge lance of very red metal, the others were adzes and hatchets. They were almost pure copper. It may be an open question whether any attempt was made at this period to harden copper by the introduction of other metals.

From the palace of Sargon there were also obtained objects of gold foil, which was not adulterated with copper or lead, but contained a considerable amount of silver ; this, however, may simply indicate that as native gold commonly contains more or less silver, it had been used in the state in which it was found without any intentional admixture. Berthelot also tested some gold objects from Egypt, the one dating from the sixth and the other from the twelfth dynasty, and found the amount of silver varied from $3^{*} 2$ to $4^{*} 5$ per cent., while the gold of the Persian period was practically pure.

But a more ancient chapter of Egyptian archreology was opened by the recent researches of M. de Morgan, late Director-General of Antiquities in Egypt. He explored an enormous tomb of a very ancient king, which he supposes to be that of Menes, of the first dynasty, approximately 4400 B.C. Among the objects found here were a long bead and two or three other morsels of metal, which M. Berthelot certifies to be of gold, together with some articles in copper. Further explorations at or near Abydos, by M. Amélineau, have shown the existence of tombs of kings about the same period containing many copper utensils, which M. Berthelot found to be of almost pure metal, but sometimes containing a little arsenic.

These tombs are now being very carefully explored by Prof. Flinders Petrie, and the results are published by the "Egyptian Exploration Fund" in three large volumes, "Diospolis Parva," and "The Royal Tombs of the Earliest Dynasties," parts i. and ii. It would appear that in these prehistoric times the metals mostly used were gold and copper; objects made of silver and lead are found, but they are rare.

As gold occurs native and is of a striking colour, we need not wonder that it attracted the attention of men in the very earliest periods. It is astonishing the large amount of exquisite gold jewellery, inlaid with gems, that has been found, not only in the tombs of Queen Ahhotpu and of the four princesses buried at Dahshur about 2350 B.C., but in these far more ancient royal tombs. In one of them Flinders Petrie found four gold bracelets encircling the arm bone of a royal personage, presumably the wife of King Zer. These are made of gold, set with turquoises and amethysts, and so beautifully wrought that the soldering cannot be detected by the eye. My analysis of the gold foil found in three of these tombs showed that it contained about I 3 per cent. of silver, and was evidently the pale gold commonly known in the Levant. The gold worked in the Nubian mines appears to have been of a purer quality.

The last paper that has been communicated by Berthelot contains a description of a very curious case, or shrine, found at Thebes. It is of the time of Queen Shapenapit, daughter of King Piankhi, who lived in the latter part of the seventh century B.C. This inlaid case is remarkable as containing, in addition to the ordinary metals of the time, a small piece of crude platinum, weighing between five and six milligrammes. It had evidently been worked with the hammer, and had probably been mistaken by the artificer for silver.

Though not himself one of the explorers in the field, Berthelot must ever be remembered for the important part he has taken in drawing attention to, and interpreting the results of their wonderful discoveries.

J. H. Gladstone. 